\title{
PENGARUH DIVIDEND PER SHARE (DPS) DAN EARNING PER SHARE (EPS) TERHADAP HARGA SAHAM PADA PERUSAHAAN SUB SEKTOR FARMASI DI BURSA EFEK INDONESIA (BEI)
}

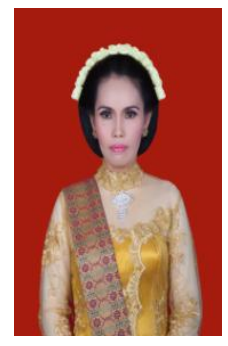

\author{
Oleh: Emma Lilianti, S.E., M.Si. \\ Dosen Fakultas Ekonomi Universitas PGRI Palembang \\ Email: liliantieachmad@yahoo.com
}

Penelitian ini bertujuan untuk mengetahui pengaruh Dividend Per Share (DPS) dan Earning Per Share (EPS) terhadap harga saham pada perusahaan sub sektor Farmasi di Bursa Efek Indonesia (BEI). Permasalahan dalam penelitian ini bagaimana pengaruh Dividend Per Share dan Earning Per Share terhadap harga saham pada perusahaan subsektor Farmasi di Bursa Efek Indonesia (BEI)?. Model analisis data dengan multiple regresion melalui uji asumsi klasik yaitu uji normalitas data, autokorelasi, multikolinearitas dan uji heterokedastisitas. Populasi yaitu seluruh perusahaan subsektor Farmasi di BEI sebanyak 10 perusahaan, dengan sampel terpilih sebanyak 9 perusahaan melalui purposive sampling. Hasil penelitian menunjukkan bahwa Dividend Per Share (DPS) dan Earning Per Share (EPS) mempunyai pengaruh terhadap harga saham pada perusahaan sub sektor Farmasi di Bursa Efek Indonesia (BEI).

\section{PENDAHULUAN}

Perkembangnya perekonomian yang kompetetif menuntut perusahaan yang melakukan ekspansi usaha, ditunjukkan dengan pesatnya perkembangan perusahaan yang terdaftar di Bursa Efek Indonesia. Pemegang saham dari Bursa Efek Indonesia adalah perusahaan pialang efek yang menjadi anggota BEI dan mereka inilah yang diperkenankan melakukan aktivitas perdagangan efek di BEI. Kegiatan mengelola efek meliputi pencatatan saham yang akan diperdagangkan, fasilitas pedagangan efek pada lantai bursa, dan kegiatan lainnya yang berhubungan dengan analisis pasar modal dan penyebaran informasi perdagangan.

Pasar modal merupakan tempat yang mempertemukan antara investor dan emiten. Melalui pasar modal inilah perusahaan yang telah go public dapat melakukan kegiatan investasi yang dinilai cukup murah bagi perkembangan usahanya, yakni menggunakan instrumen keuangan yang disebut dengan sekuritas. Investasi dipasar modal menjadi hal yang sangat penting bagi perekonomian. Keberadaan pasar modal secara spesifik menguntungkan dua pihak yang memiliki kelebihan dana dan pihak lain yang memerlukan dana. Pertumbuhan pasar modal yang sangat pesat memberi dampak positif terhadap perekonomian nasional, disamping itu dengan adanya pasar modal diharapkan adanya pemerataan hasil-hasil pembangunan melalui pemilikan sahamsaham perusahaan serta penyediaan lapangan kerja dan pemerataan kesempatan berusaha. Masyarakat dapat ikut memiliki dan menikmati keberhasilan perusahaan melalui pembagian dividen dan peningkatan harga saham. Dividen adalah pembagian keuntungan yang 
diberikan perusahaan penerbit saham tersebut atas keuntungan yang dihasilkan perusahaan. Dalam Bird in the hand theory diketahui bahwa harga saham akan sangat ditentukan oleh besarnya dividen yang dibagikan. Kebijakan dividen mempunyai dua implikasi yang pertama pada sisi pemenuhan kebutuhan dana dan yang kedua pada sisi pendapatan para pemegang saham, Kebijakan suatu perusahaan dalam mengambil keputusan apakah laba akan dibagikan sebagai dividen kepada pemegang saham atau ditahan sebagai laba ditahan dinyatakan dengan dividen per saham atau Dividen Per Share (DPS) Selain DPS harga saham juga dapat dipengaruhi oleh usaha perusahaan dalam meningkatkan laba per lembar saham atau Earning Per Share (EPS), yaitu besarnya laba yang dibagikan ke pemegang saham setelah dibandingkan dengan saham yang beredar, rasio per lembar saham merupakan rasio untuk mengukur keberhasilan manajemen dalam mencapai keuntungan bagi pemegang saham. Rasio yang rendah berarti manajemen belum berhasil untuk memuaskan pemegang saham, sebaliknya dengan rasio yang tinggi, maka kesejahteraan pemegang saham meningkat dengan pengertian lain, bahwa jika tingkat pengembalian tinggi maka akan mempengaruhi harga saham. Makin tinggi nilai EPS tentu saja menggembirakan pemegang saham dan mebuat investor untuk tertarik membeli saham.

Melalui investasi saham inilah para investor tertarik untuk berinvestasi, karena dengan berinvestasi seorang investor dihadapkan pada dua jenis keuntungan yaitu capital gain dan dividend. Capital gain merupakan selisih lebih yang diperoleh dari harga saham pada saat menjual dan membeli saham. Sedangkan
Dividend merupakan pembagian laba perusahaan kepada para pemegang saham yang besarnya sebanding dengan jumlah lembar saham yang dimiliki. Perusahaan yang bisa memberikan dividen yang besar, harga sahamnya juga akan meningkat, sebaliknya perusahaan yang terus menerus tidak membagikan dividen, maka harga sahamnya akan turun. Hal ini dapat ditentukan dengan hukum permintaan dan penawaran. Makin banyak orang membeli saham maka harga saham tersebut akan bergerak naik dan begitu sebaliknya semakin banyak orang yang menjual saham perusahaan maka harga saham tersebut akan bergerak turun.

Harga saham selalu mengalami perubahan menyebabkan investor harus mampu memperhatikan faktor-faktor yang mempengaruhi harga saham. Harga saham merupakan salah satu faktor bagi investor dalam pengambilan keputusan, pembentukan harga saham tidak terlepas dari informasi akuntansi. Salah satunya adalah informasi mengenai kebijakan dividen. Melalui informasi itulah investor mengambil keputusan dalam berinvestasi dan memprediksi prospek perusahaan dimasa mendatang. Dalam kaitannya dengan penelitian ini, penulis akan menganalisis apakah Dividend Per Share (DPS) dan Earning Per Share (EPS) berpengaruh terhadap harga saham.

Dividend Per Share (DPS) merupakan pembagian labayang dibagikan kepada semua pemegang saham secara proporsional sesuai dengan jumlah lembar saham yang dimilikinya. Informasi mengenai dividend per share sangat diperlukan untuk mengetahui berapa besar keuntungan setiap lemba saham yang akan diterima oleh para pemegang saham. Jika dividend per share yang diterima naik, maka akan mempengaruhi harga saham di 
pasar modal. Karena dengan naiknya dividend per share kemungkinan besar akan menarik investor untuk membeli saham perusahaan tersebut. Dengan banyaknya saham yang dibeli maka harga saham suatu perusahaan akan mengalami kenaikkan di pasar modal.

Earning Per Share (EPS) atau pendapatan per lembar saham adalah bentuk pemberian keuntungan yang diberikan kepada para pemegang saham dari setiap lembar saham yang dimiliki (Fahmi, 2013:96). EPS juga merupakan rasio untuk mengukur keberhasilan suatu manajemen dalam hal mencapai keuntungan bagi para pemegang saham. EPS menunjukkan kamampuan suatu perusahaan dalam menghasilkan laba untuk tiap lembar sahamnya atau gambaran mengenai sejumlah rupiah yang akan diperoleh oleh investordari setiap jumlah saham yang dimilikinya. Oleh karena itu, dengan mengetahui Earning Per Share (EPS) suatu perusahaan maka investor dapat menilai potensi pendapatan yang akan diterimanya.

Dengan demikian, earning per share dapat mencerminkan pendapatan di masa yang akan datang. Earning per share merupakan suatu indikator yang berpengaruh terhadap harga saham, karena laba perusahaan merupakan faktor yang mempengaruhi penilaian investor akan keadaan perusahaan. Apabila earning per share meningkat, investor menganggap perusahaan mempunyai prospek yang cerah di masa yang akan datang, sehingga akan meningkatkan harga saham suatu perusahaan. Selain itu, semakin tinggi nilai earning per share tentu saja menggembirakan pemegang saham, karena semakin besar laba yang disediakan oleh perusahaan untuk pemegang saham.
Research gap beberapa penelitian terdahulu yang berkaitan DPS dan EPS serta pengaruh terhadap harga saham diantaranya Prasetyo (2012) yang menyatakan secara parsial maupun simultan DPS dan EPS berpengaruh terhadap harga saham. Hasil ini berbeda dengan Saparuddin (2012) yang menyatakan secara simultan DPS dan EPS berpengaruh terhadap harga saham sedangkan secara parsial hanya DPS yang berpengaruh, sedangkan Intan (2009) yang menyatakan secara simultan DPS dan EPS berpengaruh terhadap harga saham sedangkan secara parsial hanya EPS yang berpengaruh. Sudiyanto menyatakan DPS dan EPS mempunyai pengaruh terhadap harga saham, diperkuat dengan hasil penelitian Heidar (2011). Berdasarkan pemaparan, terdapatnya ketidaksamaan antara teori dividen dengan data yang terjadi dan adanya perbedaan hasil penelitian pengaruh DPS dan EPS terhadap harga saham, sehingga penulis tertarik meneliti dengan judul "Pengaruh Dividen Per Share dan Earning Per Share terhadap Harga Saham Perusahaan Sektor Barang Konsumsi Sub Sektor Farmasi di Bursa Efek Indonesia"

Berdasarkan latar belakang di atas, rumusan masalah dalam penelitian ini adalah sebagai berikut:

1. Bagaimana pengaruh DPS dan EPS terhadap Harga Saham Perusahaan Sektor Barang Konsumsi Sub Sektor Farmasi di Bursa Efek Indonesia?

2. Bagaimana pengaruh DPS terhadap Harga Saham Perusahaan Sektor Barang Konsumsi Sub Sektor Farmasi di Bursa Efek Indonesia?

3. Bagaimana pengaruh EPS terhadap Harga Saham Perusahaan Sektor Barang Konsumsi Sub Sektor Farmasi di Bursa Efek Indonesia? 


\section{KAJIAN PUSTAKA TEORI}

\section{Pasar Modal}

Menurut Fahmi (2013: 55), pasar modal adalah tempat dimana berbagai pihak khususnya perusahaan menjual saham (stock) dan obligasi (bond) dengan tujuan dari hasil penjualan tersebut nantinya akan dipergunakan sebagai tambahan dana atau untuk memperkuat modal perusahaan. Sedangkan menurut Darmadji (2012:1), pasar modal adalah pasar untuk berbagai instrumen keuangan jangka panjang yang bisa diperjualbelikan, baik dalam bentuk utang ataupun modal sendiri.

Teori smooting theory yang dikembangkan oleh Litner yang menyatakan bahwa jumlah dividen bergantung pada keuntungan perusahaan sekarang dan tahun sebelumnya. Untuk melihat keuntungan perusahaan sekarang maka perusahaan dan investor bisa melakukan analisis rasio keuangan perusahaan tersebut. Karena dengan menganalisis rasio keuangan, baik perusahaan maupun investor akan mengetahui keadaan keuangan perusahaan dan seberapa besar perusahaan menghasilkan laba. Dengan demikian, laba perusahaan yang tinggi akan meningkatkan harga saham perusahaan (Harahap, 2013).

\section{Saham}

Menurut Martono (2010: 367), saham adalah surat bukti atau tanda kepemilikan bagian modal pada suatu perusahaan". Menurut Kasmir (2010: 205), saham merupakan tanda kepemilikan perusahaan atas nama saham yang dibelinya. Selanjutnya Fahmi (2013: 81) pengertian saham adalah:
1. Tanda bukti penyertaan kepemilikan modal/dana pada perusahaan.

2. Kertas yang tercantum dengan nilai nominal, nama perusahaan dan diikuti dengan hak dan kewajiban yang dijelaskan kepada setiap pemegangnya.

3. Persediaan yang siap untuk dijual.

Selanjutnya menurut Darmadji (2012: 5), saham (stock) merupakan tanda penyertaan atau pemilikkan seseorang atau badan dalam suatu perusahaan atau perseroan terbatas. Saham berwujud selembar kertas yang menerangkan bahwa pemilik kertas tersebut adalah pemilik perusahaan yang menerbitkan surat berharga tersebut

\section{Dividen}

Menurut Darmadji (2012: 141) dividen merupakan pembagian sisa laba bersih perusahaan yang didistribusikan kepada pemegang saham atas persetujuan RUPS. Dividen dapat berbentuk dividen tunai (cash dividend) atau dividen saham (stock dividend). Salah satu keuntungan memiliki saham adalah memperoleh dividen. Menurut Fahmi (2013:83), dividen adalah "The distribution of current of accumulated earning to the shareholders of corporation pro rate based on the number of shares owned". Artinya adalah distribusi arus akumulasi laba kepada pemegang saham korporasi tingkat pro berdasarkan jumlah saham yang dimiliki. Selanjutnya menurut Sunariyah (2011:48) "dividen yaitu pembagian keuntungan yang diberikan perusahaan penerbit saham tersebut atas keuntungan yang dihasilkan perusahaan".

Menurut Darmadji (2012:179) dividen diberikan dalam berbagai bentuk. Dilihat dari bentuk dividen yang didistribusikan kepada pemegang saham, 
dividen dapat dibedakan menjadi beberapa jenis :

1. Dividen tunai (cash dividend) : dividen yang dibagikan kepada pemegang saham dalam bentuk uang kas tersebut.

2. Dividen saham (stock dividend) : dividen yang dibagikan bukan dalam bentuk uang tunai melainkan dalam bentuk saham perusahaan tersebut.

3. Dividen proverti (property dividend) : dividen yang dibagikan dalam bentuk aktiva lain sekalian kas atau saham, misalnya aktiva tetap dan surat- surat berharga.

4. Dividen likuidasi (liquidating dividend): dividen yang diberikan kepada pemegang saham sebagai akibat diliquidasinya perusahaan. Dividen yang dibagikan adalah selisih nilai realisasi aset perusahaan dikurangi semua dengan kewajibannya.

Menurut Sudana (2011:167), terdapat tiga teori tentang kebijakan dividen yang menjelaskan pengaruh besar kecilnya dividend pay out ratio. Pengaruh kebijakan dividen tersebut adalah sebagai berikut :

\section{Teori Dividend Irrelevant}

Teori ini dikemukakan oleh Franco Modigliani dan Merton Miller yang menyatakan kebijakan dividen tidak mempengaruhi harga pasar saham perusahaan atas nilai perusahaan. Mereka berpendapat bahwa nilai perusahaan hanya ditentukan oleh kemampuan perusahaan dalam menghasilkan pendapatan dan risiko bisnis, sedangkan bagaimana membagi arus kas pendapatan menjadi dividen dan laba ditahan tidak mempengaruhi nilai perusahaan.

\section{Teori Bird-In-The-Hand}

Teori ini dikemukan oleh Myron Gordon dan John Litner yang menyatakan bahwa kebijakan dividen berpengaruh positif terhadap harga pasar saham. Artinya jika dividen yang dibagikan perusahaan semakin besar, harga pasar saham tersebut akan semakin tinggi dan sebaliknya. Hal ini terjadi karena pembagian dividen dapat mengurangi ketidakpastian yang dihadapi investor.

\section{Teori Tax Preference}

Berdasarkan teori ini, kebijakan dividen mempunyai pengaruh negatif terhadap harga pasar saham perusahaan. Artinya semakin besar jumlah dividen yang dibagikan oleh suatu perusahaan maka semakin rendah harga saham yang bersangkutan. Hal ini terjadi jika ada perbedaan antara tarif pajak personal atas pendapatan dividen dan capital gain.

\section{Dividend Per Share (DPS)}

Dividend per share merupakan rasio yang mengukur seberapa besar dividen yang dibagikan dibandingkan dengan jumlah saham yang beredar pada tahun tertentu. Rasio ini memberikan gambaran mengenai seberapa besar laba yang dibagikan dalam bentuk dividen kepada pemegang saham untuk tiap lembar saham. Menurut Tandelilin (2010: 384), untuk menghitung dividend per share dapat menggunkan rumus:

$$
\begin{gathered}
\text { DPS }=\frac{\text { Dividen Tunai }}{\text { Jumlah lembar saham yang beredar }} \\
\text { Perusahaan yang dividend per } \\
\text { share nya lebih tinggi dibandingkan }
\end{gathered}
$$
dengan perusahaan-perusahaan sejenis akan lebih diminati oleh investor, karena investor akan memperoleh kepastian modal yang ditanamkannya, yakni hasil berupa dividen. Namun perlu diingat bahwa perusahaan juga perlu memperhatikan kebutuhan investasinya, sehingga perusahaan perlu menetapkan kebijakan dviden yang berkaitan dengan penentuan pembagian pendapatan (earning) antara penggunaan untuk 
dibayarkan kepada pemegang saham sebagai dividen dan untuk digunakan dalam perusahaan yang akan diperlukan untuk investasi perusahaan.

\section{Earning Per Share (EPS)}

Menurut Tandelilin (2010:373), "Earning per share adalah laba bersih setelah bunga dan pajak yang siap dibagikan kepada pemegang saham dibagi dengan jumlah lembar saham perusahaan". Selanjutnya menurut Fahmi (2013:96), "Earning Per Share (EPS) adalah bentuk pemberian keuntungan yang diberikan kepada para pemegang saham dari setiap lembar saham yang dimiliki". Adapun rumus earning per share adalah:

\section{Kerangka Pemikiran}

$$
E P S=\frac{(\mathrm{EAT})}{\mathrm{J}_{\mathrm{sb}}}
$$

Berdasarkan rumusan masalah di atas, maka kerangka pemikiran dalam penelitian ini:

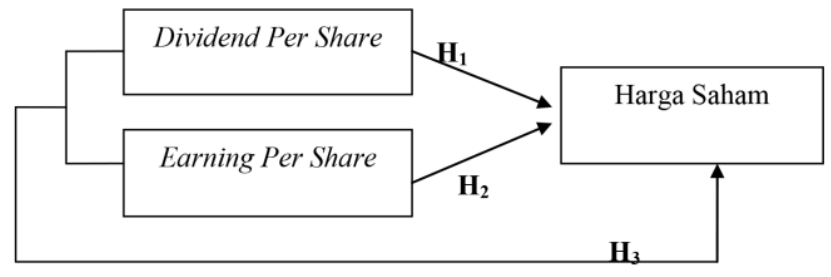

Gambar 1. Kerangka Pemikiran

\section{Hipotesis Penelitian}

Berdasarkan kerangka pemikiran diatas, peneliti merumuskan hipotesis sebagai berikut :

$\mathrm{H}_{1}$ : Dividend per share berpengaruh positif terhadap harga saham perusahaan sektor industri barang konsumsi subsektor Farmasi di BEI.

$\mathrm{H}_{2}$ : Earning per share berpengaruh positif terhadap harga saham perusahaan sektor industri barang konsumsi subsektor Farmasi di BEI.

$\mathrm{H}_{3}$ : Dividend per share dan Earning per share terhadap harga saham perusahaan sektor industri barang konsumsi subsektor Farmasi di BEI.

\section{METODELOGI PENELITIAN}

\section{Definisi Operasional}

Tabel 1. Definisi Operasional Variabel

\begin{tabular}{|c|c|c|c|}
\hline Variabel & Definisi & Indikator & Proksi \\
\hline $\begin{array}{l}\text { Dividend Per } \\
\text { Share (DPS) } \\
\qquad \mathrm{X}_{1}\end{array}$ & $\begin{array}{l}\text { Dividend per share (DPS) } \\
\text { merupakan rasio yang mengukur } \\
\text { seberapa besar dividen yang } \\
\text { dibagikan dibandingkan dengan } \\
\text { jumlah saham yang beredar pada } \\
\text { tahun tertentu (Tandelilin, } \\
\text { 2010:384). }\end{array}$ & $\begin{array}{l}\text { 1. Dividen Tunai } \\
\text { 2. Jumlah Saham } \\
\text { Beredar }\end{array}$ & DPS $=\frac{\text { Divden Tunai }}{\text { Jumlah saham beredar }}$ \\
\hline $\begin{array}{l}\text { Earning Per } \\
\text { Share } \\
{ }^{(\text {EPS })} \mathrm{X}_{2}\end{array}$ & $\begin{array}{l}\text { Earning Per Share (EPS) adalah } \\
\text { laba bersih setelah bunga dan pajak } \\
\text { yang siap dibagikan kepada } \\
\text { pemegang saham dibagi dengan } \\
\text { jumlah lembar saham perusahaan } \\
\text { (Tandelilin, 2010:373). }\end{array}$ & $\begin{array}{l}\text { 1. Laba Bersih } \\
\text { Setelah Pajak } \\
\text { 2. Jumlah Saham } \\
\text { Beredar }\end{array}$ & EPS $=\frac{\text { EAT }}{\text { Jumlah saham beredar }}$ \\
\hline $\begin{array}{l}\text { Harga Saham } \\
\text { (Y) }\end{array}$ & $\begin{array}{l}\text { Harga saham adalah harga selembar } \\
\text { kertas yang diperjualbelikan di pasar } \\
\text { modal, yang mana harga tersebut } \\
\text { dapat berubah kapan saja dan }\end{array}$ & Closing price & Rasio \\
\hline
\end{tabular}




\begin{tabular}{|l|l|l|l|}
\hline & $\begin{array}{l}\text { berubah sesuai dengan permintaan } \\
\text { dan penawaran serta kinerja } \\
\text { ekonomi mikro dan makro } \\
\text { (Darmadji dan Fakhruddin, } \\
\text { 2012:102). }\end{array}$ & & \\
\hline
\end{tabular}

Sumber: 1. Tandelilin, (2010: 384)

2. Tandelilin, 92010: 373)

3. Darmadji (2012: 102)

\section{Populasi dan Sampel}

Populasi dalam penelitian ini adalah 10 perusahaan subsektor farmasi yang terdapat di BEI. Teknik Sampel yang digunakan adalah Nonprobalitiy sampling merupakan teknik sampling yang tidak memberikan peluang atau kesempatan yang sama bagi setiap unsur atau anggota populasi untuk dipilih menjadi sample. Teknik nonprobability sampling yang digunakan adalah Purposive Sampling. yaitu merupakan teknik penentuan sampel dengan pertimbangan tertentu. Penulis memilih perusahaan sebagai sampel dengan memilih perusahaan yang benarbenar memiliki kompetensi dengan topik penelitian. Berdasarkan pertimbangan atau kriteria yang dimaksud maka sampel terpilih 9 perusahaan sebagai sample dari total 10 perusahaan sub sektor Farmasi di BEI periode 2012-2016. Pengumpulan data dilakukan dengan studi perpustakaan (library reserach). Sampel terpilih yang memenuhi kriteria dalam penelitian ini adalah:

Tabel 2. Sampel Penelitian

\begin{tabular}{|c|c|l|c|c|}
\hline No & Kode & $\begin{array}{c}\text { Nama } \\
\text { Emiten }\end{array}$ & $\begin{array}{c}\text { Tanggal } \\
\text { IPO }\end{array}$ & Sampel \\
\hline 1 & DVLA & $\begin{array}{l}\text { Daya Varia } \\
\text { Laboratoria } \\
\text { Tbk }\end{array}$ & $\begin{array}{c}11 \text { Nop } \\
1994\end{array}$ & $\sqrt{ }$ \\
\hline 2 & INAF & $\begin{array}{l}\text { Indofarma } \\
\text { (persero) Tbk }\end{array}$ & $\begin{array}{c}17 \text { April } \\
2001\end{array}$ & $\sqrt{ }$ \\
\hline 3 & KAEF & $\begin{array}{l}\text { Kimia Farma } \\
\text { (Persero) Tbk }\end{array}$ & $\begin{array}{c}4 \text { Juli } \\
2001\end{array}$ & $\sqrt{ }$ \\
\hline 4 & KLBF & $\begin{array}{l}\text { Kalbe Farma } \\
\text { (Persero) Tbk }\end{array}$ & $\begin{array}{c}30 \text { Juli } \\
1991\end{array}$ & $\sqrt{ }$ \\
\hline
\end{tabular}

\begin{tabular}{|c|c|c|c|c|}
\hline 5 & MERK & $\begin{array}{l}\text { Merck } \\
\text { Indonesia } \\
\text { Tbk }\end{array}$ & $\begin{array}{c}23 \text { Juli } \\
1981\end{array}$ & $\sqrt{ }$ \\
\hline 6 & PYFA & $\begin{array}{l}\text { Pyridam } \\
\text { Farma Tbk }\end{array}$ & $\begin{array}{c}16 \mathrm{Okt} \\
2001\end{array}$ & $\sqrt{ }$ \\
\hline 7 & SCPI & $\begin{array}{l}\text { Merck Sharp } \\
\text { Dohme } \\
\text { Pharma Tbk }\end{array}$ & $\begin{array}{l}8 \text { Juni } \\
1990\end{array}$ & $\sqrt{ }$ \\
\hline 8 & SIDO & $\begin{array}{l}\text { Industri Jamu } \\
\& \text { Farmasi } \\
\text { Sido Muncul } \\
\text { Tbk }\end{array}$ & $\begin{array}{c}18 \text { Des } \\
2013\end{array}$ & $\mathrm{X}$ \\
\hline 9 & SQBB/SQBI & $\begin{array}{l}\text { Taisho } \\
\text { Parmaceutical } \\
\text { Indonesia } \\
\text { Tbk }\end{array}$ & $\begin{array}{c}29 \\
\text { Maret } \\
1983\end{array}$ & $\sqrt{ }$ \\
\hline 10 & TSPC & $\begin{array}{l}\text { Tempo Scan } \\
\text { Pasific Tbk }\end{array}$ & $\begin{array}{c}17 \text { Jan } \\
1994\end{array}$ & $\sqrt{ }$ \\
\hline
\end{tabular}

Sumber: www.idx.co.id

\section{HASIL DAN PEMBAHASAN}

Hasil Uji Asumsi Klasik

Pengujian jenis ini digunakan untuk menguji asumsi, apakah model regresi yang digunakan dalam penelitian ini layak atau tidak, uji asumsi klasik terdiri atas :

\section{a. Hasil Uji Normalitas}

Uji normalitas bertujuan untuk menguji apakah dalam model regresi, variabel pengganggu atau residual memiliki distribusi normal atau tidak. Uji normalitas data dilakukan dengan uji OneSample Kolmogrov-Smirno Test dengan bantuan software SPSS 22. Berikut hasil dari pengujian normalitas dapat dilihat pada tabel dibawah ini : 
Tabel 3. Hasil Uji Normalitas Data

Sumber: Hasil pengolahan data dengan SPSS versi 22, Tahun 2017

\begin{tabular}{|ll|r|r|r|}
\hline & & Ln_DPS & Ln_EPS & Ln_HS \\
\hline $\mathrm{N}$ & & 45 & 45 & 45 \\
Normal & Mean & 4,6375 & 5,9244 & 8,1030 \\
Parameters ${ }^{\mathrm{a}, \mathrm{b}}$ & Std. Deviation & 1,82152 & 1,14330 & 1,1869 \\
& & & 5 \\
Most Extreme & Absolute &, 163 &, 169 &, 158 \\
Differences & Positive &, 163 &, 126 &, 158 \\
& Negative &,- 098 &,- 169 &,- 149 \\
Test Statistic & &, 163 &, 169 &, 158 \\
Asymp. Sig. (2-tailed) &, $085^{\mathrm{C}}$ &, $063^{\mathrm{c}}$ &, $110^{\mathrm{C}}$ \\
\hline
\end{tabular}

Dari tabel 3 menunjukkan bahwa nilai Asymp Sig. (2-tailed) dari dividend per share sebesar 0,085, earning per share sebesar 0,063, dan Harga Saham sebesar 0,110. Nilai Asymp Sig. (2-tailed) tersebut $>0,05$, maka dapat diambil kesimpulan bahwa variabel dividend per share, earning per share dan harga saham secara statistik telah terdistribusi secara normal dan layak digunakan sebagai data untuk penelitian.

\section{b. Uji Autokorelasi}

Uji autokorelasi bertujuan untuk menguji apakah dalam suatu model regresi linear ada korelasi antara kesalahan pengganggu pada periode $\mathrm{t}-1$ (sebelumnya). Pengujian ini dilakukan dengan uji Durbin-watson test dengan bantuan SPSS 22. Berikut hasil pengujian dapat dilihat pada tabel dibawah ini:

Tabel 4. Hasil Uji Autokorelasi

\begin{tabular}{|c|c|c|c|c|c|}
\hline Model & $\mathrm{R}$ & $\begin{array}{c}\mathrm{R} \\
\text { Square }\end{array}$ & $\begin{array}{l}\text { Adjusted } \\
\text { R Square }\end{array}$ & $\begin{array}{l}\text { Std. Error of } \\
\text { the Estimate }\end{array}$ & $\begin{array}{l}\text { Durbin- } \\
\text { Watson }\end{array}$ \\
\hline 1 & $368^{\mathrm{a}}$ & ,635 &, 094 & 5216,35574 & 1,715 \\
\hline
\end{tabular}

Dari tabel 4 tertera nilai DW sebesar 1,715 dengan demikian nilai DW berada antara (1,55 sampai 2,46), maka dapat disimpulkan bahwa tidak terjadi masalah autokorelasi dalam penelitian ini.

\section{c. Uji Heteroskedastisitas}

Uji heteroskedastisitas bertujuan untuk menguji apakah dalam model regresi terjadi ketidaksamaan variance dari residual 1 pengamatan ke pengamatan yang lain. Ada beberapa cara untuk mendeteksi ada atau tidaknya heteroskedastisitas.

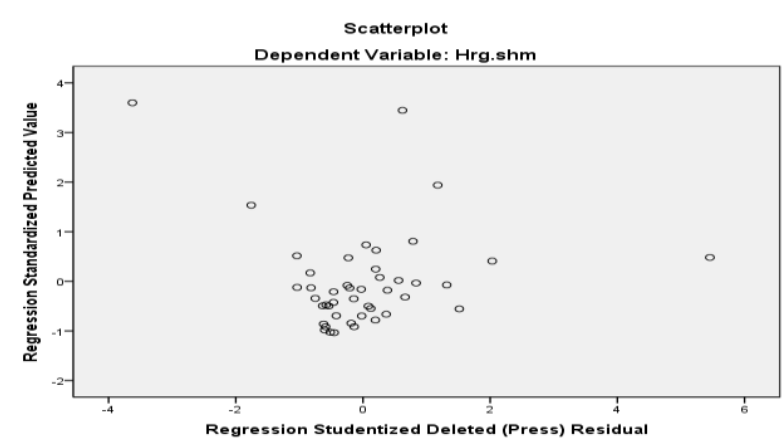

Gambar.1. Hasil Uji Heterokedastisitas d. Uji Multikolonieritas

Pengujian ini dilakukan untuk menguji ada tidaknya kolerasi antara sesama variabel independen yang ada dalam model regresi dengan melihat tolerance dan Variance inflation Factor (VIF). Nilai tolerance yang rendah sama dengan VIF yang tinggi (karena VIF = 1/tolerance). Berikut hasil pengujian dapat dilihat pada tabel dibawah ini:

\section{Tabel 5. Hasil Uji Multikolinearitas}

\begin{tabular}{|c|c|c|}
\hline \multirow[b]{2}{*}{ Model } & \multicolumn{2}{|c|}{ Collinearity Statistics } \\
\hline & Tolerance & VIF \\
\hline $1 \quad$ (Constant) & & \\
\hline DPS & ,543 & 1,842 \\
\hline EPS & ,543 & 1,842 \\
\hline
\end{tabular}

Sumber: Hasil pengolahan data dengan SPSS versi 22, Tahun 2017

Dari tabel 5 dapat dilihat bahwa nilai VIF dari model analisis pada penelitian ini $<10$, yaitu divided per share dan earning per share memiliki VIF 1,842. Dan nilai tolerance $>0,10$, yaitu dividend per share dan earning per share memiliki nilai tolerance 0,543. Maka dapat disimpulkan 
bahwa tidak terjadi multikolonieritas pada penelitian ini.

\section{Hasil Model Analisis}

Regresi linier berganda, yaitu metode statistik yang digunakan untuk mengetahui pengaruh variabel terikat terhadap variabel bebas, dapat dilihat pada tabel berikut ini:

Tabel.6. Hasil Analisis Regresi Linear

\section{Berganda}

\begin{tabular}{|c|c|c|c|c|}
\hline \multirow[b]{2}{*}{ Model } & \multicolumn{2}{|c|}{$\begin{array}{l}\text { Unstandardize } \\
\text { d Coefficients }\end{array}$} & \multirow{2}{*}{\multicolumn{2}{|c|}{$\begin{array}{c}\begin{array}{c}\text { Standardized } \\
\text { Coefficients }\end{array} \\
\text { Beta }\end{array}$}} \\
\hline & B & $\begin{array}{l}\text { Std. } \\
\text { Error }\end{array}$ & & \\
\hline 1 (Constant) & 3,572 & 1,215 & & \\
\hline EPS & 0,387 & 1,238 & & 277 \\
\hline DPS & 0,294 & 1,261 & & 262 \\
\hline
\end{tabular}

Sumber: Hasil pengolahan data dengan SPSS versi 22, Tahun 2017

Dari tabel diatas dapat disusun persamaan regresi linier berganda sebagai berikut:

$$
\mathrm{Y}=3,572+0,387 \mathrm{X}_{1}+0,294 \mathrm{X}_{2}
$$

Berdasarkan model regresi ini terlihat bahwa :

a. Konstanta sebesar 3,572 menunjukan bahwa jika variabel independen (Dividend Per Share dan Earning Per Share) dianggap konstan (bernilai nol) maka harga saham akan tetap ada sebesar 0,572.

b. Koefisien regresi Dividend Per Share adalah sebesar 0,387 artinya apabila DPS mengalami kenaikan sebesar satu satuan maka akan menyebabkan harga saham meningkat sebesar 0,387 satuan.

c. Koefisien regresi Earning Per Share adalah sebesar 0,294 artinya apabila EPS mengalami kenaikan sebesar satu satuan maka akan menyebabkan harga saham meningkat sebesar 0,294 satuan.

\section{Hasil Uji Determinasi}

Analisis Determinasi $\left(\mathrm{R}^{2}\right)$ digunakan untuk mengetahui persentasepengaruh variabel independen terhadap variabel dependen. Dari uji ini akandiketahui seberapa besar variabel independen akan mampu menjelaskan variabeldependennya, sedangkan sisanya dijelaskan oleh variabel lainnya yang tidakdimasukkan dalam model regresi.

Tabel 7. Hasil Uji Determinasi

\begin{tabular}{|l|c|r|r|r|r|}
\hline Model & $\mathrm{R}$ & $\begin{array}{c}\mathrm{R} \\
\text { Square }\end{array}$ & $\begin{array}{c}\text { Adjusted } \mathrm{R} \\
\text { Square }\end{array}$ & $\begin{array}{c}\text { Std. Error of } \\
\text { the Estimate }\end{array}$ & $\begin{array}{c}\text { Durbin- } \\
\text { Watson }\end{array}$ \\
\hline 1 &, $368^{\mathrm{a}}$ &, 635 &, 094 & 5216,35574 & 1,715 \\
\hline \multicolumn{5}{|c|}{ Sumber: Hasil pengolahan data }
\end{tabular}
dengan SPSS versi 22, Tahun 2017

Dari hasil uji determinasi pada tabel diatas, besarnya nilai $\mathrm{R}^{2}$ dalam model regresi sebesar 0,635. Hal ini menunjukkan bahwa besar pengaruh variabel independen (dividend per share dan earning pershare)terhadap variabel dependen (harga saham) yang dapat diterangkan oleh persamaan ini sebesar $63,5 \%$. Sedangkan sisanya sebesar $36,3 \%$ dipengaruhi oleh faktor lain yang tidak dimasukkan dalam model regresi. Jika nilai $\mathrm{R}^{2}$ mendekati 1 maka variabel bebas semakin kuat pengaruhnya terhadap variabel dependen.

\section{Hasil Uji Hipotesis}

\section{a. Hasil Uji F}

Uji Simultan (Uji F) digunakan untuk menguji pengaruh variabel dividend per share dan earning per share terhadap harga saham

Tabel 8. Hasil Uji F

\begin{tabular}{|c|c|c|c|c|c|}
\hline Model & $\begin{array}{l}\text { Sum of } \\
\text { Squares }\end{array}$ & Df & Mean Square & $\mathrm{F}$ & Sig. \\
\hline 1 Regression & $1,791 \mathrm{E} 8$ & 2 & 89550988,806 & 3,291 &, $047^{\mathrm{a}}$ \\
\hline Residual & $1,143 \mathrm{E} 9$ & 42 & 27210367,247 & & \\
\hline Total & $1,322 \mathrm{E} 9$ & 44 & & & \\
\hline
\end{tabular}

Sumber: Hasil pengolahan data dengan SPSS versi 22, Tahun 2017

Hasil uji $\mathrm{F}$ menunjukkan bahwa nilai $\operatorname{sig} \mathrm{F}$ sebesar $0,047<\operatorname{sig} \alpha 0,05$ artinya 
terdapat pengaruh DPS dan EPS terhadap harga saham perusahaan subsektor farmasi, H0 ditolak.

\section{b. Uji Koefisien Regresi (Uji t)}

Uji koefisien regresi digunakan untuk melihat tingkat signifikan masing-masing koefisien regresi.

Tabel 9. Hasil Uji hipotesis t

\begin{tabular}{|c|c|c|c|c|c|}
\hline \multirow[b]{2}{*}{ Model } & \multicolumn{2}{|c|}{$\begin{array}{l}\text { Unstandardized } \\
\text { Coefficients }\end{array}$} & \multirow{2}{*}{$\begin{array}{c}\text { Standardized } \\
\text { Coefficients }\end{array}$} & \multirow[b]{2}{*}{$t$} & \multirow[b]{2}{*}{ Sig. } \\
\hline & B & Std. Error & & & \\
\hline (Constant) & 3572,235 & 1215,988 & & 2,938 & ,005 \\
\hline EPS & 2,387 & 1,238 & 277 & 1,928 & ,041 \\
\hline DPS & 2,294 & 1,261 & ,262 & 1,819 & ,050 \\
\hline
\end{tabular}

Sumber: Hasil pengolahan data dengan SPSS versi 22, Tahun 2017

Dari Tabel 9 variabel dividend per share menunjukkan nilai sig $\mathrm{t}$ sebesar $0,041<\operatorname{sig} \alpha=0,05$ dan variabel earning per share menunjukkan nilai sig t sebesar $0,050 \leq \operatorname{sig} \alpha=0,05$. Maka $\mathrm{H}_{0}$ ditolak dan $\mathrm{H}_{\mathrm{a}}$ diterima, artinya terdapat pengaruh dividend per share dan earning per share secara parsial terhadap harga saham pada perusahaan subsektor farmasi di BEI.

\section{Pembahasan}

Hasil penelitian sesuai dengan teori bird in the hand theory yang dikemukan oleh Gordon yang berpendapat bahwa Dividend Per Share mempunyai nilai yang tinggi bagi investor daripada pendapatan modal. Karena Dividend Per Share lebih pasti daripada pendapatan modal. Teori ini menyatakan bahwa investor menyukai dividen karena kas di tangan lebih bernilai dari pada kekayaan dari bentuk lain. Harga saham perusahaan sangat ditentukan oleh dividen yang dibagikan, artinya semakin tinggi dividen yang dibagikan, semakin tinggi pula harga saham perusahaan. Dividend per share (DPS) merupakan rasio yang mengukur seberapa besar dividen yang dibagikan dibandingkan dengan jumlah saham yang beredar pada tahun tertentu. Rasio ini memberikan gambaran mengenai seberapa besar laba yang dibagikan dalam bentuk dividen kepada pemegang saham untuk tiap lembar saham.

Teori smooting theory yang dikembangkan oleh Litner yang menyatakan bahwa jumlah deviden bergantung pada keuntungan perusahaan sekarang dan tahun sebelumnya. Untuk melihat keuntungan perusahaan sekarang maka perusahaan dan investor bisa melakukan analisis rasio keuangan perusahaan tersebut. Dengan menganalisis rasio keuangan, baik perusahaan maupun investor akan mengetahui keadaan keuangan perusahaan dan seberapa besar perusahaan menghasilkan laba. Dengan demikian laba perusahaan yang tinggi akan meningkatkan harga saham perusahaan. Dengan peningkatan Earning Per Share menandakan bahwa perusahaan berhasil meningkatkan taraf kemakmuran investor dan mendorong investor untuk menambah jumlah modal yang ditanam pada perusahaan. Makin tinggi nilai Earning Per Share akan menggembirakan pemegang saham karena semakin besar laba yang disediakan untuk pemegang saham dan berakibatkan meningkatnya laba maka harga saham akan mengalami kenaikan.

\section{Kesimpulan}

Hasil uji $\mathrm{F}$ menunjukkan bahwa nilai sig F sebesar $0,047<\operatorname{sig} \alpha 0,05$ artinya terdapat pengaruh DPS dan EPS terhadap harga saham perusahaan subsektor farmasi. Hasil uji t menunjukkan dividend per share dengan nilai sig t sebesar 0,041 $<\operatorname{sig} \alpha=0,05$ dan variabel earning per share menunjukkan nilai sig $\mathrm{t}$ sebesar $0,050 \leq \operatorname{sig} \alpha=0,05$. Maka $\mathrm{H}_{0}$ ditolak dan 
$\mathrm{H}_{\mathrm{a}}$ diterima, artinya terdapat pengaruh dividend per share dan earning per share secara parsial terhadap harga saham pada perusahaan subsektor farmasi di BEI.

\section{Daftar Pustaka}

Darmadji, Tjiptono, dan Fakhruddin. 2012. Pasar Modal Di Indonesia. Edisi Ketiga. Jakarta : Salemba Empat.

Fahmi, Irham. 2013. Pengantar Pasar Modal. Edisi Pertama. Bandung : Alfabeta.

Ghozali, Imam. 2011. Aplikasi Analisis Multivariat dengan Program IBM SPSS 19. Edisi Kelima. Semarang: Universitas Diponegoro.

Harahap, Sofyan Syafri. 2013. Analisis Kritis Atas Laporan Keuangan. Cetakan Kesebelas. Jakarta : Penerbit Rajawali Pers.

Heidar, Sayed., et al. (2011). Fitting The Relationship Between Financial Variables and Stock Price Through Fuzzy Regression Case Study : Iran Khodro Company. International Journal of Business and Social Science. Vol. 2 No. 11, June 2011

Intan, Taranika. 2009. Pengaruh Dividend Per Share dan Earning Per Share Terhadap Harga Saham pada Perusahaan Go Publik di Bursa Efek Indonesia. Universitas Sumatera Utara.

Kasmir. 2010. Pengantar Manajemen Keuangan. Jakarta : Kencana Prenada media Group.

Martono, Agus Harjito. 2010. Manajemen Keuangan. Yogyakarta : Ekonisia.

Prasetyo, Galih. (2011). Pengaruh Financial Leverage, Earning Per Share (EPS), Dan Dividen Per Shre (DPS) terhadap Harga Saham.
Skripsi Fakultas Ekonomi Universitas Pasundan.

Saparuddin. (2012). Pengaruh Earning Per Share (EPS) dan Dividen Per Share (DPS) Terhadap Harga Saham Pada Perusahaan Coal Mining yang Terdaftar di BEI Periode 20072010. Jurnal Jurusan Manajemen, Fakultas Ekonomi dan Bisnis, Universitas Negeri Gorontalo

Sudana, Made. 2011. Manajemen Keuangan Perusahaan, Teori \& Praktek. Jakarta: Erlangga.

Sunariyah. 2011. Pengantar Pengetahuan Pasar Modal. Edisi Keenam. Yogyakarta: UPP-AMP YKPN.

Sudiyatno, Bambang dan Suharmanto, Toto. (2011). Kinerja Keuangan Konvensional, Economic Value Added dan Return Saham (Studi Pada Perusahaan Makanan dan Minuman). Jurnal Dinamika Manajemen (JDM) Vol. 2, No. 2, 2011, pp: 153-161.

Tandelilin, Eduardus. 2010. Portofolio dan Investasi Teori dari Aplikasi. Edisi Pertama. Yogyakarta : Kanisius.

\section{BIODATA PENULIS}

$\begin{array}{ll}\text { Nama } & : \text { Emma Lilianti, S.E., M.Si. } \\ \text { NIDN } & : 0214087502 \\ \text { Pangkat/Golongan } & : \text { Lektor/ III.c } \\ \text { PTS } & : \text { Fakultas Ekonomi Universitas } \\ & \text { PGRI Palembang } \\ \text { No. HP } & : \text { 0852-19863630 } \\ \text { email } & : \text { liliantieachmad@yahoo.com }\end{array}$

